\title{
WNT4 Gene
}

National Cancer Institute

\section{Source}

National Cancer Institute. WNT4 Gene. NCI Thesaurus. Code C20807.

This gene plays a role in hormonal signaling and is involved in sex determination. 